\title{
Bioclimatic map of Tay Nguyen at scale 1:250,000 for setting up sustainable ecological economic models
}

\author{
Nguyen Khanh Van ${ }^{1 *}$, Pham Thi Ly ${ }^{1}$, Nguyen Thi Hong ${ }^{2}$ \\ ${ }^{I}$ Institute of Geography, Vietnam Academy of Science and Technology, Hanoi, Vietnam \\ ${ }^{2}$ College of Education, Thai Nguyen University
}

Received 15 November 2014

\begin{abstract}
A study on development of a system for bioclimatic classification criteria and construction of a bioclimatic map of Tay Nguyen region at scale of 1/250,000 was conducted, based on statistical analysis of bioclimatic characteristics of Tay Nguyen, comparing with those of other regions of Vietnam. The system of classification criteria was developed based on 4 factors, namely: mean annual temperature $\left(T_{N}\right)$, total annual rainfall $\left(R_{N}\right)$, length of cold season $(N)$ and length of dry season length $(n)$. The thermal-humid indicators, featuring seasonal constraints (for tropical plants) as well as the thresholds for their division, were selected based on the ecological characteristics of vegetation and their role for the formulation, structure, appearance of the natural vegetation types of Tay Nguyen region. Results showed bioclimatic resources of Tay Nguyen territory is rich and diverse reflecting in 23 different bioclimatic units of a total of 57 separate polygons. That partly explains the diversity of vegetation types of Tay Nguyen. Study of bioclimatic classification has both a scientific and practical significance. Bioclimatic classification provides an important information for mapping ecological landscape of Tay Nguyen; A bioclimatic resource assessment of a specific territory is a necessary scientific basis for proposing the development orientation of economic sectors and establishment of sample sustainable economic models in Tay Nguyen territory.
\end{abstract}

Keywords: Bioclimatic classification, bioclimatic criteria, vegetation ecology.

(C) 2014 Vietnam Academy of Science and Technology

\section{Introduction}

Climate is one of the essential factors determining the formation and development of natural vegetation (on genesis base), affecting classification and diversity of the landscape of a territory. To recommend the orientation of appropriate use for territory and sustainable ecological economic development, we need to establish the divided rule of natural landscapes and typical ecologies. From the perspective of ecological view, bioclimatology plays an important role as one of the factors in formation of the natural landscape. Monsoonal, humid tropical climatic regime associated with geographical

*Corresponding author, Email: ngkhvan@gmail.com location and topography have created diversified segmentation of bioclimatic conditions in different regions of our country. This report presents the findings of the study on climatic characteristics, construction of a bioclimatic map for Tay Nguyen, in order to assess its bioclimatic resources toward an establishment of ecological economic models, an appropriate agricultural and forestry production, plant layout, crop seasons in accordance with natural rules of the territory, contributing to environmental protection of the rich and beautiful Tay Nguyen territory.

\section{Study area, methodology and databases}

Tay Nguyen is a plateau to the west of Nam Truong Son mountain, with geographical 
Nguyen Khanh Van et al./Vietnam Journal of Earth Sciences 36 (2014)

coordinates in the range of $11^{\circ} 12^{\prime} \mathrm{N}-15^{\circ} 25^{\prime} \mathrm{N}$; $107^{\circ} 12^{\prime} \mathrm{E}-108^{\circ} 00^{\prime} \mathrm{E}$.

Tay Nguyen has 5 provinces arranged from north to south including Kon Tum, Gia Lai, DakLak, DakNong and Lam Dong. Total area of Tay Nguyen is $54,474 \mathrm{~km}^{2}$, accounted for $16.6 \%$ of the national area.

The following research methods were used in this study: Statistical methods in meteorological climatological data processing; Climate classification method. General survey methodology; Fieldwork methods; Mapping and geographic information systems (GIS).

Database of bioclimatic map of Tay Nguyen at 1:250,000 scale includes yearly climate data of 15 meteorological stations, 12 hydrological stations and 29 rain gauge sites of 5 provinces of Tay Nguyen, topographic map at the scale of 1:250,000 (Characteristics of meteorological, hydrological stations and rain gauge sites in Tay Nguyen region are shown in Appendix 1).

\section{Results and discussion}

Bioclimatology is the interdisciplinary science of climatology and ecology, studying the effects of climate, weather on living organisms in the ecosystem/natural synthetic ecology (Nguyen Khanh Van, 2006). Bioclimatic researching is also studying the suitability of bioclimatic conditions for organisms in the ecosystems, improving the productivity of the crops and livestock in agroforestry ecosystems. Thus, the concept of bioclimatic conditions of organisms in ecosystems or natural synthetic system is rather broad, this report just focused on investigating and classifying bioclimatic conditions of natural vegetation (based on the genetic source), for the establishment of ecological economic models, proposal of development orientation for sustainable agricultural and forestry production; and in some specific cases, sample plant layouts, crop seasons areproposed in accordance with the laws of nature, contributing to the protection of natural resources and environment inTay Nguyen.

\subsection{Classification systems of bioclimate in Vietnam}

Contributions to bioclimate classifications in Vietnam notably include the classification system of bioclimate by $\mathrm{Vu} \mathrm{Tu}$ Lap (Vu Tu Lap, 2002) landscape research in Northern Vietnam; the system by Thai Van Trung is providing classification of forest vegetation in Vietnam (Thai Van Trung, 1978). Other works have found application in forestry (Lam Cong Dinh, 1992) and in studying tropical monsoon landscape of Vietnam (Nguyen Khanh Van et al., 1999).

Bioclimatic research has become increasingly useful in providing a scientific basis, proposing direction for a rational use of natural resources. To study bioclimate of different geographic regions in Vietnam, the authors in Institute of Geography have conducted the following projects: bioclimatic classification of Tay Nguyen (1987), bioclimatic classification of 9 mountainous provinces in Northern Viet Nam (1995), bioclimatic classification of Southeast (Viet Nam) region (1996), bioclimatic classification of the NorthCentral region (1997) (Nguyen Khanh Van et al., 1999). Bioclimatic characteristics used in the classification are: annual average temperature $\left(T_{N}\right)$, totalannual rainfall $\left(R_{N}\right)$, the length of the cold season $(\mathrm{N})$, the length of the dry season $(\mathrm{n}) /$ or mean rainfall of dry period (for Tay Nguyen 1987). Threshold values of these indexes depend on specific climate characteristics of each region as well as the ecological characteristics of the living organisms that are the subject of the study.

\subsection{Criteria system of bioclimatic classification in Tay Nguyenat scale 1: 250,000}

Based on experience from construction of bioclimatic maps for different regions and at different scales, in this report, criteria systems of bioclimatic classification in Tay Nguyen have been set up taking into account the following specific features of climatic conditions and vegetation ecology of the study area such as:

- Climate of Tay Nguyen is tropical monsoon climate of plateau with temperature change in accordance with the rule of elevations, large diurnal temperature amplitude, humidity conditions in a sharp contrast between two seasons - the rainy season and dry seasons.

- Connecting to the presence of vegetation in this territory, climatic conditions as quoted in (Thai Van Trung, 1978) showed that from low to 
Nguyen Khanh Van et al./Vietnam Journal of Earth Sciences 36 (2014)

high altitudes of the region, the following natural vegetation types exist: : (i) The tropical evergreen closed forest (in Blao, Di Linh, DakLak, southwestern of Pleiku); (ii) The tropical deciduous closed forest (in Pleiku, DakLak); (iii) The tropical broad-leaved deciduous semiarid woodland forest (in Ea Sup, DakLak, Di Linh); (iv) The tropical coniferous (needle leaves) semiarid woodland forest (in DakLak); (v) The tropical coniferous semiarid woodland forest at low mountain (in Da Lat, DakLak, Di Linh); (vi) The tropical woodland, shrub, savanna (in Cheo Reo, Buon Ma Thuot), (vii) The tropical evergreen closed forest at low mountain (in Kon Tum, DakLak), (viii) The tropical mixing broadleaf and needle leaves forest at low mountain (in Ngoc Linh, Chu Yang Sin); (ix) The tropical coniferous closed forest at medium mountain (in Ngoc Linh, Chu Yang Sin).

Requirements of criteria selection for Tay Nguyen bioclimate are:

- Selected criteria must be representative, reflecting the nature and seasonal distribution characteristics (thermal and moisture) over space, time and altitude.

- Selected criteria must represent the nature of ecoclimate, reflecting the law of distribution, the growth and development of the natural vegetation types existed on the territory of study.

To assess the bioclimatic conditions of thestudy area, factors reflecting thermal - moisture basic conditions are selected such as: mean annual air temperature and total annual rainfall.

\subsubsection{Thermal criteria system}

Analysis of observed data at stations in Tay Nguyen showed that on the whole territory, surface temperatures ranging between 18 and $24^{\circ} \mathrm{C}$ are differentiated with space, latitude and elevation. In the lowlands, annual average temperatures fluctuate from $20^{\circ} \mathrm{C}$ to $23^{\circ} \mathrm{C}$. In the mountainous areas, the higher altitude the lower temperature is, the longer the coldseason is in accordance with the laws that temperatures decrease with height.

\section{- Mean annual temperature}

Thermal resource in the territory is evaluated through mean annual air temperature of Tay Nguyen $T_{N}$, corresponding to the total accumulated temperature - a very valuable factor in agroclimatology research and widely used in planning for farming practice. Temperature $\mathrm{T}_{\mathrm{N}}$ is classified into the following levels (Table 1):

Table 1. Classification of annual average temperature $T_{N}$

\begin{tabular}{|c|c|c|c|c|c|}
\hline \multirow[b]{2}{*}{ Sign, name } & \multicolumn{2}{|c|}{ Temperature levels } & \multicolumn{2}{|c|}{ Elevations } & \multirow[b]{2}{*}{ Characteristics of vegetation and plant } \\
\hline & $\mathrm{T}_{\mathrm{N}}$ & Total temperature & $\begin{array}{c}\text { North of } \\
\text { Tay Nguyen }\end{array}$ & $\begin{array}{c}\text { South of } \\
\text { Tay Nguyen }\end{array}$ & \\
\hline$\overline{\text { I- Very hot }}$ & $\mathrm{T}_{\mathrm{N}}>24^{\circ} \mathrm{C}$ & $>8,800^{\circ} \mathrm{C}$ & $<200 \mathrm{~m}$ & $<300 \mathrm{~m}$ & $\begin{array}{l}\text { Tropical vegetation and plant with adequate } \\
\text { heat }\end{array}$ \\
\hline II- Hot & $22^{\circ} \mathrm{C}<\mathrm{T}_{\mathrm{N}} \leq 24^{\circ} \mathrm{C}$ & $8,000^{\circ} \mathrm{C}-8,800^{\circ} \mathrm{C}$ & $200-600 \mathrm{~m}$ & $300-700 m$ & $\begin{array}{l}\text { Tropical vegetation and plant with adequate } \\
\text { heat }\end{array}$ \\
\hline III- Warm & $20^{\circ} \mathrm{C}<\mathrm{T}_{\mathrm{N}} \leq 22^{\circ} \mathrm{C}$ & $7,300^{\circ} \mathrm{C}-8,000^{\circ} \mathrm{C}$ & $600-1,000 \mathrm{~m}$ & $700-1,100 m$ & $\begin{array}{l}\text { Tropical vegetation exist and may have some of } \\
\text { temperature plant and sub-tropical plants }\end{array}$ \\
\hline IV-Cool & $18^{\circ} \mathrm{C}<\mathrm{T}_{\mathrm{N}} \leq 20^{\circ} \mathrm{C}$ & $6,500-7,300^{\circ} \mathrm{C}$ & $1,000-1,400 m$ & $1,100-1,500 \mathrm{~m}$ & $\begin{array}{l}\text { Tropical vegetation exist. Sub-tropical plants } \\
\text { and temperature plants are diverse in types }\end{array}$ \\
\hline V- Cold & $\mathrm{T}_{\mathrm{N}} \leq 18^{\circ} \mathrm{C}$ & $<6500^{\circ} \mathrm{C}$ & $>1,400 \mathrm{~m}$ & $>1,500 \mathrm{~m}$ & $\begin{array}{l}\text { Tropical plants may exist but temperate plants } \\
\text { are dominant, especially vegetables and flower } \\
\text { plants of cold areas; the conifers are grown. }\end{array}$ \\
\hline
\end{tabular}

(I) Very hot, $\mathrm{T}_{\mathrm{N}}>24^{\circ} \mathrm{C}$, equivalent to the total operating temperature more than $8,800^{\circ} \mathrm{C}$. For Tay Nguyen, where the elevation is less than $200 \mathrm{~m}$ in Ea Sup, Ban Don, Ayun Pa, Krong Pa, or less than $300 \mathrm{~m}$ in $\mathrm{Da}$ Teh, both $\mathrm{T}_{\mathrm{N}}$ and total operating temperatures satisfy conditions above. In overall, very hot temperature conditions are favorable for tropical plants to flourish.
(II) Hot, $22^{\circ} \mathrm{C}<\mathrm{T}_{\mathrm{N}} \leq 24^{\circ} \mathrm{C}$ equivalent to the total annual temperature from $8,000-8,800^{\circ} \mathrm{C}$. The areas with elevations from 200 to $600 \mathrm{~m}$ in North of Tay Nguyen and from 300 to $700 \mathrm{~m}$ in South of Tay Nguyen are guaranteed with such conditions of heat. This thermal belt is very favorable for vegetation and tropical plants to grow all over the year. 
Nguyen Khanh Van et al./Vietnam Journal of Earth Sciences 36 (2014)

(III) Warm, $20^{\circ} \mathrm{C}<\mathrm{T}_{\mathrm{N}} \leq 22^{\circ} \mathrm{C}$, equivalent to the total annual temperature: $7,300-8,000^{\circ} \mathrm{C}$. The areas with height from $600-1,000 \mathrm{~m}$ in North of Tay Nguyen and from $700-1,100 \mathrm{~m}$ in South of Tay Nguyen. This thermal belt is favorable for the development of tropical plants and some plants of temperate or subtropical origin.

(IV) Cool, $18^{\circ} \mathrm{C}<\mathrm{T}_{\mathrm{N}} \leq 20^{\circ} \mathrm{C}$, equivalent to the total annual temperature: $6,500-7,300^{\circ} \mathrm{C}$ : Available in mountainous areas of Northern Kon Tum at elevation: 1,000-1,400 m. In South of Tay Nguyen, this temperature appears in mountainous region of Lam Dong and a part of DakLak with height: 1,100$1,500 \mathrm{~m}$. Sub-tropical and temperate plants are more dominant than tropical plants in this temperature belt.

(V) Cold, $\mathrm{T}_{\mathrm{N}} \leq 18^{\circ} \mathrm{C}$ is equivalent to the total annual temperature below $6,500^{\circ} \mathrm{C}$ : Available in $\mathrm{Kon}$ Tum - the area around Ngoc Linh (with altitudes above 1,400 m); in Da Lat and mountainous region of northern Da Lat (with altitudes above 1,500m). Temperature conditions are suitable for the development of temperate plants, flowers and vegetables originated from cold areas and coniferous forest. Therefore, this region has become famous of cultivation and exportation of flowers and vegetables all over the country.

\section{- Length of the cold season}

The change in length of the cold season in a given region is closely related to its geographic location and altitude (Houérou H.N. et al., 1993). The length of the cold season is determined by the number of cold months with a monthly verage temperatures below $18^{\circ} \mathrm{C}$ (Vu Tu Lap, 2002; Nguyen Khanh Van, 1993), sign "N". For Tay Nguyen, cold season length is divided into the following levels (Table 2):

Table 2. Classification of cold season length

\begin{tabular}{|c|c|c|c|}
\hline Sign & Name & $\begin{array}{c}\text { Number of } \\
\text { coldmonths }(\mathrm{N})\end{array}$ & Altitude \\
\hline 0 & No cold season & 0 & $<600-700 \mathrm{~m}$ \\
\hline 1 & $\begin{array}{l}\text { Short cold } \\
\text { season }\end{array}$ & 1 & $600 / 700-1000 / 1100 \mathrm{~m}$ \\
\hline 2 & $\begin{array}{l}\text { Average cold } \\
\text { season }\end{array}$ & $2-3$ & $1000 / 1100 \mathrm{~m}-1400 / 1500 \mathrm{~m}$ \\
\hline 3 & $\begin{array}{l}\text { Long cold } \\
\text { season }\end{array}$ & $\geq 4$ & $>1400 / 1500 \mathrm{~m}$ \\
\hline
\end{tabular}

The data on annual average temperature, the number of cold months of stations in Tay Nguyen are presented in Appendix 2.

\subsubsection{Criteria system of humid regime}

It is believed that temperature affects the distribution of plant species, while wet - dry condition affects the appearance, shaping and status of vegetation (Legris P. et al., 1989; Nguyen Khanh Van, 2006). Thai Van Trung studied the genetic ecology of forest vegetation in Vietnam proved that dry-wet mode is a dominant factor, determining the formation of climate types of primitive natural vegetation in a large area in monsoon tropical climate, such as Vietnam.

Among the climatic - hydrological factors forming genetic vegetation, wet-dry regime in this study is described as a complex combination consisting of the total of annual rainfall and the number of dry month.

\section{- Criteria of rainfall}

As an indicator of the humid potential supply for an area, rainfall-humidity indicator was chosen as the totalannual rainfall $\left(\mathrm{R}_{\mathrm{N}}\right)$. By studying the rainfall regime throughout the territory in relation to natural genetic vegetation (Legris et al., 1989; Thai Van Trung, 1978; Nguyen Khanh Van, 1993) suggests the following levels of the total annual rainfall inTay Nguyen:

(A) Excessive rain, $\mathrm{R}_{\mathrm{N}}>2,500 \mathrm{~mm}$, indicating excess moisture conditions, to ensure dense evergreen forests with broadleaf trees exist in any circumstances.

(B) Abundant rain, 2,000mm $<\mathrm{R}_{\mathrm{N}} \leq 2,500 \mathrm{~mm}$, enough moisture, corresponding to the existence of closed evergreen vegetation.

(C) Moderate rain, $1,500 \mathrm{~mm}<\mathrm{R}_{\mathrm{N}} \leq 2,000 \mathrm{~mm}$, corresponding to evergreen or semi-deciduous forests (depending on dry season).

(D) Little rain, $1200 \mathrm{~mm}<\mathrm{R}_{\mathrm{N}} \leq 1500 \mathrm{~mm}$, corresponding to the type of vegetation in dry deciduous forests.

(E) Very little rain, $R_{N} \leq 1,200 \mathrm{~mm}$, corresponding to dry deciduous forest and scrub.

- Criteria of dry season length

Looking at the distribution of total yearly rainfall in a territory, the number of dry months has a great influence on the structure, external appearance of the vegetation (dry month is the month with total of rainfall $\leq 50 \mathrm{~mm}$ (Houérou et 
Nguyen Khanh Van et al./Vietnam Journal of Earth Sciences 36 (2014)

al.,1993; Vu Tu Lap, 2002; Thai Van Trung, 1978), so beside the total annual rainfall, rainyhumid criteria, the number of dry months is added as an indicator for climate constraints to plant species in particular or tropical vegetation in general.

Based on the results of studies (Nguyen DucNgu, 1988; Thai Van Trung, 1978; Nguyen Khanh Van, 1993) the dryness in Tay Nguyen is divided into the following levels (Table 3 ):

Table 3. Classification of dry season length

\begin{tabular}{|c|c|c|c|}
\hline Sign & Name & $\begin{array}{c}\text { Number of dry } \\
\text { months (n) }\end{array}$ & Present of vegetation \\
\hline $\mathrm{a}$ & $\begin{array}{l}\text { Short dry } \\
\text { season }\end{array}$ & $\mathrm{a} \leq 2$ months & $\begin{array}{l}\text { Type of tropical rain } \\
\text { forest, closed evergreen } \\
\text { forest with broad leaves. }\end{array}$ \\
\hline $\mathrm{b}$ & $\begin{array}{l}\text { Medium dry } \\
\text { season }\end{array}$ & $\mathrm{n}=3-4$ months & $\begin{array}{l}\text { Type of rain season } \\
\text { evergreen closed forest } \\
\text { or type of mid-decidous } \\
\text { forest depend on total } \\
\text { annual rainfall and } \\
\text { ability of maintaining } \\
\text { water of the ground }\end{array}$ \\
\hline $\mathrm{c}$ & $\begin{array}{l}\text { Long dry } \\
\text { season }\end{array}$ & $\mathrm{n} \geq 5$ months & $\begin{array}{l}\text { Type of mid- deciduous } \\
\text { broad leaves sparse } \\
\text { forest or deciduous broad } \\
\text { leaves sparse forest in } \\
\text { dry season. }\end{array}$ \\
\hline
\end{tabular}

The data on annual average rainfall, the number of dry, arid and desert dry months of stations in Tay Nguyen are presented in Appendix 3.

\subsection{Building bioclimatic map of Tay Nguyen, scale 1:250,000}

Criteria system of bioclimatic division in study area is shown in matrix Table 4. Based on analysis, overlaying the information of selected bioclimatic factors $\left(T_{N}, R_{N}, N, n\right)$, the bioclimatic map of TayNguyen was built (Fig.1).

\section{- Bioclimaticunits of Tay Nguyen}

There are 23 bioclimatic units in the bioclimatic map of Tay Nguyen, scale 1: 250,000 in which bioclimatic unit IIIC1b appears the most with 11 times, VA3a appears 5 times, IIIB1a appears 4 times; and 5 types of bio-climate No 12 , 14, 17, 22, 23 appear 3 times; some units of bioclimate appear 2 times and up to 8 units of bioclimate appear only once (Table 5).

From the above mentioned bioclimatic units, the unit of IICOb occupies the largest area of 17 , $260 \mathrm{~km}^{2}$, equivalent to $31.5 \%$ of the whole region; the second largest area equivalents to unit of IIIC1b with $5,667.8 \mathrm{~km}^{2}$ (accounting for $10.3 \%$ ) and the unit has the smallest area is VB3a with $92.2 \mathrm{~km}^{2}$ (accounting for only $0.2 \%$ ).

Table 4. Legend system of bioclimatic map of Tay Nguyen, scale 1:250.000

\begin{tabular}{|c|c|c|c|c|c|c|c|c|c|c|}
\hline $\begin{array}{l}\text { Humid regime } \\
\text { Thermal regime }\end{array}$ & $\begin{array}{l}\text { Total of } \\
\text { annual rainfall }\end{array}$ & $\begin{array}{l}\text { A: Exces } \\
(K n \geq 25\end{array}$ & $\begin{array}{l}\text { ssive rain } \\
5(0)\end{array}$ & $\begin{array}{l}\text { B: Abun } \\
2.000 \text { S }\end{array}$ & $\begin{array}{l}\text { udant nin } \\
\text { Koc2.500) }\end{array}$ & $\begin{array}{l}\text { C: Modera } \\
(1,500) \leq \mathrm{B}\end{array}$ & $\begin{array}{l}\text { e rain } \\
n<2.000)\end{array}$ & $\begin{array}{l}\text { D. Little rai } \\
\text { (1 } 200 \leqslant \mathrm{Rr}\end{array}$ & $\left.\operatorname{lin}_{n<1} 500\right)$ & $\begin{array}{l}\text { E: Very } \\
\text { little nain } \\
(\text { Rn<1.200) }\end{array}$ \\
\hline $\begin{array}{l}\text { Average ammual } \\
\text { temperature }\end{array}$ & $\begin{array}{l}\text { Dry sason } \\
\text { Cold season }\end{array}$ & $\begin{array}{l}\text { a. } \\
\text { Short dry } \\
\text { season } \\
(\mathrm{a} \leq 2)\end{array}$ & $\begin{array}{c}\text { b. } \\
\text { Average dry } \\
\text { seasise } \\
(3 \leq n \leq 4)\end{array}$ & $\begin{array}{l}\text { a. } \\
\text { Shert dry } \\
\text { season } \\
\text { (n } \leq 2)\end{array}$ & $\begin{array}{c}\text { b. } \\
\text { Average } \\
\text { dry sesson } \\
(3 \leq n \leq 4) i\end{array}$ & $\begin{array}{c}\text { b. } \\
\text { Average } \\
\text { dry scason } \\
(3 \leq n \leq 4)\end{array}$ & $\begin{array}{c}c, \\
\text { Long dry } \\
\text { season } \\
(\mathrm{n} \times 5)\end{array}$ & $\begin{array}{c}\text { b. } \\
\text { Average dry } \\
\text { season } \\
(3 \leq n \leq 4)\end{array}$ & $\begin{array}{l}\text { Long dry } \\
\text { season } \\
\text { (n 25) }\end{array}$ & $\begin{array}{l}\text { b. } \\
\text { Averinge dry } \\
\text { scason } \\
(3 \leq n \leq 4)\end{array}$ \\
\hline $\begin{array}{l}\text { V. Cold climate } \\
\left(T_{n} 518 \mathrm{C}\right)\end{array}$ & $\begin{array}{l}\text { 3. Averape } \\
\text { cold period } \\
\$(4 \text { mooths })\end{array}$ & ionit & & Vilives: & verios & & & & & \\
\hline $\begin{array}{l}\text { W. Cool } \\
\text { climate } \\
\left(18<\mathrm{Tn}_{\mathrm{n}} \leq 20^{\circ} \mathrm{C}\right)\end{array}$ & $\begin{array}{l}\text { 2. Shont cold period } \\
\text { nghin (2-3 mooths) }\end{array}$ & nuters & & NHE=1! & Naved & ncesi & & & & \\
\hline $\begin{array}{l}\text { II. Warn climate } \\
\left.\text { (20)Tn } \leq 22^{\circ} \mathrm{C}\right)\end{array}$ & $\begin{array}{l}\text { 1. Very short } \\
\text { cold period } \\
\text { ngain (2-3 months) }\end{array}$ & inder & & amated & imunar & ntun:41 & & intitaze & & \\
\hline $\begin{array}{l}\text { II. Hot climate } \\
\left(22<\mathrm{Tn} \leq 24^{\prime} \mathrm{C}\right)\end{array}$ & $\begin{array}{l}0 . \text { No periont } \\
\text { of cold }\end{array}$ & ment: & & 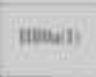 & Itanez & mon:? & & imencts & atsher) & \\
\hline $\begin{array}{l}\text { L. Very hol } \\
\text { climate } \\
\text { (Tn>24 C) }\end{array}$ & $\begin{array}{l}\text { 0. No period } \\
\text { of cold }\end{array}$ & & & & & & ISAm! & пและ11 & unsin & yeit \\
\hline
\end{tabular}

Noes: (") The number of occurances of bioclimatic units 
Nguyen Khanh Van et al./Vietnam Journal of Earth Sciences 36 (2014)

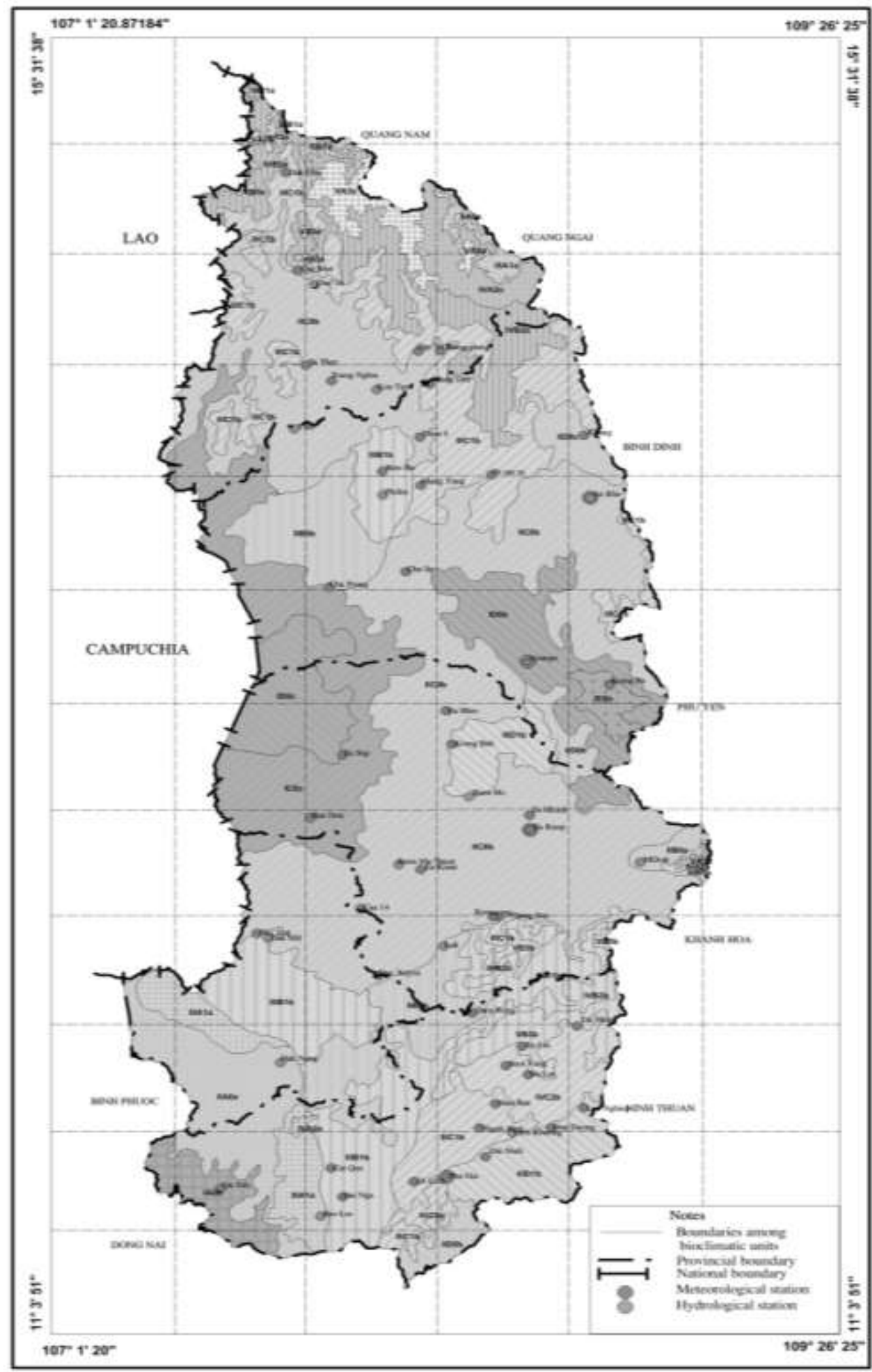

Figure 1. Bioclimatic map of Tay Nguyen, at scale 1:250,000 
Nguyen Khanh Van et al./Vietnam Journal of Earth Sciences 36 (2014)

Description of the differentiation of bioclimatic units in Tay Nguyen territory was conducted from low lands to hills and mountains; from unit of the driest bio-climate to the wettest bio-climate, in the following order:

1. IE0b: Very hot bioclimate, no cold period, very little rain (below 1,200mm/year), average dry season, appearing in Krong Pa district of Gia Lai province with a small area $\left(33.8 \mathrm{~km}^{2}\right)$.

2. ID0c: Very hot bioclimate, no cold period, little rain, long dry season appearing only once in the area of Ea Sup district, DakLak province.

3. ID0b: Very hot bioclimate, no cold period, little rain and average dry season. This type occurs in the eastern province of Gia Lai and a small part in DakLak province.

4. IC0c: Very hot bioclimate, no cold period, moderate rain and long dry season. This type occurs only once in the west of Tay Nguyen with elevations below $300 \mathrm{~m}$ stretching from several districts of Kon Tum province through Gia Lai, DakLak and expanding to a small part of DakNong province.

5. IA0b: Very hot bioclimate, no cold period, excessive rain and average dry season. This type happens only once in Da Teh district of Lam Dong province.

6. IID0c: Hot bioclimate, no cold period, little rain, long dry season appearing only once with a relatively small area in Kbang district, Gia Lai province.

7. IID0b: Hot bioclimate, no period of cold, little rain and average dry season appearing twice with a small area of Krong Pa district, Gia Lai province and south of Di Linh district, Lam Dong province.

8. IICOb: Hot bioclimate, no cold period, moderate rain, average dry season. This type only appears twice but occupies the largest area of 17, $260 \mathrm{~m}^{2}$, accounting for $31.5 \%$ of Tay Nguyen area. It appears in the district of southwest Kon Tum province such as Sa Thay district, Kon Tum town, Dak Ha district, Dak To district,Ngoc Hoi district, some districts of Northern Gia Lai such as An Khe and Chu Se, occupying most of DakLak province and a part of DakNong province.
9. IIB0b: Hot bioclimate, no cold period, abundant rain and average dry season: Appeared twice in Duc Co and IaGrai district, Gia Lai province and in the bordering area of three provinces of DakLak, DakNong and Lam Dong.

10. IIB0a: Hot bioclimate, no cold period, abundant rain, short dry season. This type appeared once in M'Drak district, DakLak province.

11. IIA0a: Hot bioclimate, no cold period, excessive rain, short dry season. It is available twice in the height from 200/300 to 600/700 m, with a large area in DakR'Lap district, DakNong province and a part in the Bao Lam, Cat Tien districts, Lam Dong province; and a very small area in the eastern Kong Plong district, Kon Tum province.

12. IIID1b: Hot bioclimate, short cold period, little rain and average dry season. This type appears in KrongBuk district, DakLak province and Don Duong and Duc Trong districts, Lam Dong province.

13. IIIC1b: Warm bioclimate, short cold period, medium rain and average dry seasons. This type appears in the territory the most with 11 times, scattered in some districts of Kon Tum province such as Ngoc Hoi, DakGley, Dak Ha, Kon Ray, expanding down to Chu Pah, DakDoa, Mang Yang, Kbang, a part of Kong Chro, Ia Pa district, Gia Lai province and Di Linh district, Lam Dong province. The area of this type is the second largest, after type of IICOb.

14. IIIB1a: Warm bioclimate, short cold period, abundant rain and short dry season. This type appears 4 times in which 3 times in the north of DakGley district, Kon Tum province and one time in the M'Drak district, DakLak province.

15. IIIB1b: Warm bioclimate, short cold period, abundant rain and average dry season: Appeared 3 times in the Bien Ho area, Gia Lai province, in Dak Song district, DakNong province and a part of Di Linh, Bao Lam district, Lam Dong province.

16. IIIA1a: Warm bioclimate, excessive rain, short cold period and short dry season. On the map, this type appears 3 times in Kong Plong 
Nguyen Khanh Van et al./Vietnam Journal of Earth Sciences 36 (2014)

district, Kon Tum province; in DakR'lap district, DakNong province and in BaoLoc, Bao Lam district, Lam Dong province.

17. IVC2b: Cool bioclimate, average cold period, little rain and average dry season: Appeared twice in the southern Tay Nguyen, in the areas of $\mathrm{Da}$ Lat and Di Linh of Lam Dong province.

18. IVB2b: Cool bioclimate, average cold period, abundant rain and average dry season. This type appears twice in Lak, Krong Bong of DakLak province and in Lac Duong of Lam Dong province.

19. IVB2a: Cool bioclimate, average cold period, abundant rain and short dry season. This type appears only once at the altitude belt between 11000 and $1400 \mathrm{~m}$ surrounding Nam Truong Son range in the Kon Tum - Gia Lai region.

20. IVA2a: Cool bioclimate, average period of cold, excessive rain and short dry season. This type appears 3 times in Kong Plong, Kon Tum province, Bao Lam, Lam Dong province and in the M'Drak district, DakLak province.

21. VB3b: Cold bioclimate, long period of cold, abundant rain and average dry season. This type appears 3 times in Krong Bong and M'Drak, DakLak province and in the area of Da Lat of Lam Dong province.

22. VB3a: Cold bioclimate, long period of cold, abundant rain and short dry season. This type appears 3 times in the altitude of more than $1400 \mathrm{~m}$ in some peaks of Kon Tum province. This bioclimatic type occupies the smallest area of Tay Nguyen.

23. VA3a: Cold bioclimate, long cold period, excessive rain and short dry season appearing 5 times, mainly in peaks with altitude of more than $1400 \mathrm{~m}$ in DakGley, Dak To and Kong Plong of Kon Tum province and M'Drak of DakLak province.

Based on the bioclimatic characteristics of the vegetation types in Tay Nguyen, it is possible to group bioclimatic units with close characteristics of thermal-humid conditions and seasonal constraints into bioclimatic types, corresponding to 9 vegetation types listed in section 2.2 of this report.
Table 5. Statistic area and times of appearance of bioclimatic units in Tay Nguyen

\begin{tabular}{|c|c|c|c|c|}
\hline \multirow{3}{*}{ Order } & \multirow{3}{*}{$\begin{array}{c}\text { Bioclimatic } \\
\text { unit }\end{array}$} & \multicolumn{3}{|c|}{ Source: Summaried from GIS } \\
\hline & & \multicolumn{2}{|c|}{ Area } & \multirow{2}{*}{$\begin{array}{c}\text { Times of } \\
\text { appearance }\end{array}$} \\
\hline & & $\mathrm{Km}^{2}$ & $\overline{\%}$ & \\
\hline 1 & $\mathrm{IE} 0 \mathrm{~b}$ & 363.8 & 0.7 & 1 \\
\hline 2 & ID0c & $1,543.0$ & 2.8 & 1 \\
\hline 3 & ID0b & $2,121.0$ & 3.9 & 1 \\
\hline 4 & $\mathrm{ICOc}$ & $4,397.0$ & 8.0 & 1 \\
\hline 5 & $\mathrm{IA} 0 \mathrm{~b}$ & 823.2 & 1.5 & 1 \\
\hline 6 & IID0c & 519.3 & 0.9 & 1 \\
\hline 7 & IIDOb & 731.0 & 1.3 & 2 \\
\hline 8 & $\mathrm{IICOb}$ & $17,260.0$ & 31.5 & 2 \\
\hline 9 & IIBOb & $3,164.0$ & 5.8 & 2 \\
\hline 10 & IIB0a & 224.5 & 0.4 & 1 \\
\hline 11 & IIA0a & $2,390.4$ & 4.4 & 2 \\
\hline 12 & IIID1b & $2,014.1$ & 3.7 & 2 \\
\hline 13 & IIIC1b & $5,667.8$ & 10.3 & 11 \\
\hline 14 & IIIB $1 b$ & $4,820.6$ & 8.8 & 3 \\
\hline 15 & IIIB1a & 157.7 & 0.3 & 4 \\
\hline 16 & IIIA1a & $1,484.4$ & 2.7 & 3 \\
\hline 17 & IVC2b & $1,230.9$ & 2.2 & 2 \\
\hline 18 & IVB2b & 763.8 & 1.4 & 2 \\
\hline 19 & IVB2a & $2,613.0$ & 4.8 & 1 \\
\hline 20 & IVA2a & 854.5 & 1.6 & 3 \\
\hline 21 & VB3b & 825.5 & 1.5 & 3 \\
\hline 22 & VB3a & 92.2 & 0.2 & 3 \\
\hline 23 & VA3a & 747.1 & 1.4 & 5 \\
\hline Sum & 23 units & $54,808.8$ & 100,0 & 57 polygons \\
\hline
\end{tabular}

\section{Conclusions}

Overall, results of the study of Tay Nguyen bioclimatic classification show that the regional bioclimatic resources are very rich, corresponding to the diversity of vegetation types from tropical, subtropical to temperate plant species (by elevation) and from tropical evergreen seasonal closed forests to semi-deciduous forests and deciduous forests in dry season of Tay Nguyen.

In particular, in plateaus with the altitude of more than 1,500 meters such as Da Lat, Lam Vien plateau, or Di Linh plateau, some species of vegetables, flowers of temperate zone origin (cold climate) can grow well; these areas are also known for coniferous woodlands, similarly as they are in temperate latitudes. With this natural privilege, Tay Nguyen has a solid premise to develop many sustainable ecological economic models in an abundant and diverse agriculture and forestry, potentially bringing high economic benefits to Tay Nguyen. 
Nguyen Khanh Van et al./Vietnam Journal of Earth Sciences 36 (2014)

This study is a part of project: "Research, valuation of synthetic source of nature, fluctuation in resource using and the establishment some sustainable economic models for major geographical areas of Tay Nguyen region" (code TN3/T03) funded by the $3^{\text {rd }}$ Tay Nguyen program, to whom the authors extend their thanks and appreciation.

\section{References}

Lam Cong Dinh, 1992: Bioclimatic applications in forestry in Vietnam. Science and Technology Publishing House, Hanoi.

Houérou, H.N., Popov, G.F., See, L., 1993: Agrobioclimatic Classification of Africa (Working paper) - FAO Agrometeorogy Series, $\mathrm{N}^{\circ} 6.227$ pp.

Vu Tu Lap, 2002: Vietnam natural geography.Education Publishing House, Hanoi.

Legris, P., Blasco, F., 1989: Classification and mapping of vegetation types in tropical Asia (Reviewed by K.D. Singh) - FAO of the United Nations, Rome. 135 pp.
Nguyen Duc Ngu, 1988: Climate of Tay Nguyen. Monographs of $2^{\text {nd }}$ Tay Nguyen Program. Vietnam Academy of Science and Technology.

Thai Van Trung, 1978: Eco-genesis and classification of forest vegetation of Vietnam (From ecosystem perspective), Second edition, with correction, Science and Techniques Publishing House, Ha Noi. 276 pp. (In Vietnamese, Resume in French, Summary in English, Russian and Spanish).

Nguyen Khanh Van, 1993: Bioclimatic Typology of Vietnam Journal Izvestia, Geographical Series, Russian Academy of Sciences, Moscow (6) pp. 114-123 (in Russian: НгуенКханьВан 1993: ТипологиябиослиматовВьетнама. Известия,СерияГеографическая, РоссийскаяАкадемияНаук, Москва).

Nguyen Khanh Van, 2006: Bioclimatic basis (Master curriculum), Hanoi Pedagogical University Publishing House of.

Nguyen Khanh Van, Nguyen Thi Hien, 1999: The available methods of bioclimatic classification in Vietnam. Vietnam Journal of Earth Sciences No. 2, Academy of Science and Technology of Vietnam, Hanoi.

\section{Appendix 1}

Technical specifications of meteorological, hydrological stations and rain gauges in Tay Nguyen

\begin{tabular}{|c|c|c|c|c|c|}
\hline $\mathrm{N}$ & Name of stations & Longitude & Latitude & Elevation $(\mathrm{m})$ & types of stations \\
\hline $\mathrm{I}$ & KON TUM & & & & \\
\hline 1 & ĐakGlei & $107^{\circ} 44$ & $15^{\circ} 05$ & & Rain gauge site \\
\hline 2 & Đak Mot & $107^{\circ} 46$ & $14^{\circ} 45$ & & Hydrological station \\
\hline 3 & Đak To & $107^{\circ} 49^{\prime}$ & $14^{\circ} 42^{\prime}$ & 620 & Meteorological station \\
\hline 4 & $\mathrm{Pe} \mathrm{Me} \mathrm{Re}$ & $108^{0} 08$ & $14^{\circ} 28$ & & Hydrological station \\
\hline 5 & Kong Plong & $108^{\circ} 12$ & $14^{\circ} 28$ & & Hydrological station \\
\hline 6 & Sa Thay & $107^{\circ} 47$ & $14^{\circ} 25$ & & Rain gauge site \\
\hline 7 & TrungNghia & $107^{\circ} 52$ & $14^{\circ} 22$ & & Rain gauge site \\
\hline 8 & Mang Den & $108^{\circ} 10$ & $14^{\circ} 21$ & & Rain gauge site \\
\hline 9 & Kon Tum & $107^{\circ} 37$ & $14^{\circ} 20$ & 538 & Meteorological station \\
\hline II & GIA LAI & & & & \\
\hline 10 & Yaly & $107^{\circ} 45$ & $14^{\circ} 12$ & 547 & Meteorological station \\
\hline 11 & Thon 4 & $108^{\circ} 08$ & $14^{\circ} 10$ & & Rain gauge site \\
\hline 12 & Kbang & $108^{\circ} 38$ & $14^{\circ} 10$ & & Rain gauge site \\
\hline 13 & Bien Ho & $108^{\circ} 01$ & $14^{\circ} 03$ & & Rain gauge site \\
\hline 14 & Po Me Re & $108^{\circ} 21$ & $14^{\circ} 02$ & & Hydrological station \\
\hline 15 & Mang Yang & $108^{\circ} 08$ & $14^{\circ} 00$ & & Rain gauge site \\
\hline 16 & Pleiku & $108^{\circ} 01$ & $13^{\circ} 58$ & 779 & Meteorological station \\
\hline 17 & An Khe & $108^{\circ} 39$ & $13^{\circ} 57$ & 422 & Meteorological station \\
\hline 18 & Chu Se & $108^{\circ} 05$ & $13^{\circ} 42$ & & Rain gauge site \\
\hline 19 & Chu Prong & $107^{\circ} 51$ & $13^{\circ} 39$ & & Rain gauge site \\
\hline 20 & Auyun $\mathrm{Pa}$ & $108^{\circ} 27$ & $13^{\circ} 23$ & 160 & Meteorological station \\
\hline 21 & Krong Pa & $108^{\circ} 42$ & $13^{\circ} 18$ & & Rain gauge site \\
\hline III & ĐAK LAK & & & & \\
\hline 22 & EaH'leo & $108^{\circ} 12$ & $13^{\circ} 13$ & 614 & Rain gauge site \\
\hline
\end{tabular}


Nguyen Khanh Van et al./Vietnam Journal of Earth Sciences 36 (2014)

\begin{tabular}{|c|c|c|c|c|c|}
\hline $\mathrm{N}$ & Name of stations & Longitude & Latitude & Elevation (m) & types of stations \\
\hline 23 & KrongBuk & $108^{\circ} 13$ & $13^{\circ} 06$ & & Rain gauge site \\
\hline 24 & Ea Sup & $107^{\circ} 53$ & $13^{\circ} 04$ & & Rain gauge site \\
\hline 25 & Buon Ho & $108^{\circ} 16$ & $12^{\circ} 55$ & 707 & Meteorological station \\
\hline 26 & Ban Don & $107^{\circ} 47$ & $12^{\circ} 51$ & & Hydrological station \\
\hline 27 & EaH'Dinh & $108^{\circ} 27$ & $12^{\circ} 51$ & & Rain gauge site \\
\hline 28 & EaKNop & $108^{\circ} 27$ & $12^{\circ} 48$ & & Rain gauge site \\
\hline 29 & Buon Ma Thuot & $108^{\circ} 03$ & $12^{\circ} 41$ & 470 & Meteorological station \\
\hline 30 & M'Drak & $108^{\circ} 47$ & $12^{\circ} 41$ & 419 & Meteorological station \\
\hline 32 & EaKmat & $108^{\circ} 07$ & $12^{\circ} 40$ & 516 & Rain gauge site \\
\hline 31 & KrongKmar & $108^{\circ} 20$ & $12^{\circ} 30$ & & Rain gauge site \\
\hline 33 & GiangSơn & $108^{\circ} 21$ & $12^{\circ} 30$ & & Hydrological station \\
\hline 34 & Lak & $108^{\circ} 11$ & $12^{\circ} 24$ & 423 & Meteorological station \\
\hline IV & ĐAK NONG & & & & \\
\hline 35 & Cau 14 & $107^{\circ} 56$ & $12^{\circ} 32$ & & Hydrological station \\
\hline 36 & Duc Lap & $107^{\circ} 37$ & $12^{\circ} 27$ & & Rain gauge site \\
\hline 37 & Đak Mil & $107^{\circ} 39$ & $12^{\circ} 26$ & 760 & Meteorological station \\
\hline 38 & ĐucXuyen & $107^{\circ} 59$ & $12^{\circ} 18$ & & Hydrological station \\
\hline 39 & ĐacNong & $107^{\circ} 41$ & $12^{\circ} 00$ & 631 & Meteorological station \\
\hline $\mathrm{V}$ & LAM ĐONG & & & & \\
\hline 40 & ĐamRong & $108^{\circ} 16$ & $12^{\circ} 10$ & & Rain gauge site \\
\hline 41 & ĐaNhim & $108^{\circ} 35$ & $12^{\circ} 07$ & & Rain gauge sitent \\
\hline 42 & XaLat & $108^{\circ} 25$ & $12^{\circ} 03$ & & Rain gauge site \\
\hline 43 & SuoiVang & $108^{\circ} 22$ & $11^{\circ} 59$ & & Rain gauge site \\
\hline 44 & ĐaLat & $108^{\circ} 26$ & $11^{\circ} 57$ & 1509 & Meteorological station \\
\hline 45 & Nam Ban & $108^{\circ} 20$ & $11^{\circ} 51$ & & Rain gauge site \\
\hline 46 & Lac Nghiep & $108^{\circ} 36$ & $11^{\circ} 50$ & & Rain gauge site \\
\hline 47 & ThanhBinh & $108^{\circ} 17$ & $11^{\circ} 46$ & & Hydrological station \\
\hline 48 & Đon Duong & $108^{\circ} 30$ & $11^{\circ} 46$ & & Rain gauge site \\
\hline 49 & Lien Khuong & $108^{\circ} 23$ & $11^{\circ} 45$ & 957 & Meteorological station \\
\hline 50 & ĐaiNinh & $108^{\circ} 18$ & $11^{\circ} 40$ & & Hydrological station \\
\hline 51 & Cat Que & $107^{\circ} 50$ & $11^{\circ} 38$ & & Rain gauge site \\
\hline 52 & PhuGia & $108^{\circ} 11$ & $11^{\circ} 36$ & & Rain gauge site \\
\hline 53 & Di Linh & $108^{\circ} 05$ & $11^{\circ} 35$ & & Rain gauge site \\
\hline 54 & DạTeh & $107^{\circ} 30$ & $11^{\circ} 34$ & & Rain gauge site \\
\hline 55 & ĐaiNga & $107^{\circ} 52$ & $11^{\circ} 32$ & & Hydrological station \\
\hline 56 & BaoLoc & $107^{\circ} 48$ & $11^{\circ} 28$ & 840 & Meteorological station \\
\hline
\end{tabular}

Appendix 2

Monthly, Yearly average temperatures and the number of cold months in Tay Nguyen

\begin{tabular}{|c|c|c|c|c|c|c|c|c|c|c|c|c|c|c|}
\hline Stations & 1 & 2 & 3 & 4 & 5 & 6 & 7 & 8 & 9 & 10 & 11 & 12 & Year & Cold months \\
\hline Dak To & 19.1 & 21.0 & 23.1 & 24.4 & 24.5 & 24.0 & 23.5 & 23.2 & 22.9 & 22.0 & 21.0 & 19.4 & 22.3 & 0 \\
\hline Kom Tum & 20.8 & 22.6 & 24.6 & 25.8 & 25.4 & 24.9 & 24.4 & 24.2 & 24.0 & 23.5 & 22.3 & 20.9 & 23.7 & 0 \\
\hline Pleiku & 19.1 & 20.7 & 22.7 & 24.1 & 24.0 & 23.1 & 22.4 & 22.3 & 22.3 & 21.8 & 20.8 & 19.3 & 21.9 & 0 \\
\hline An Khe & 19.8 & 21.2 & 23.7 & 25.3 & 25.7 & 26.4 & 25.8 & 25 & 24.6 & 23.1 & 21.2 & 20.6 & 23.6 & 0 \\
\hline Ayun $\mathrm{Pa}$ & 23.1 & 22.7 & 25.3 & 28.3 & 27.8 & 28.3 & 27.5 & 27.1 & 26.3 & 26.0 & 24.3 & 22.7 & 25.8 & 0 \\
\hline Buon Ho & 20.2 & 22.8 & 23.5 & 25.4 & 25.9 & 24.9 & 23.8 & 23.3 & 23.5 & 22.5 & 20.8 & 19.4 & 22.0 & 0 \\
\hline Buon Ma Thuot & 20.4 & 22.2 & 22.5 & 24.9 & 25.9 & 24.8 & 24.5 & 24.7 & 23.9 & 23.8 & 23.2 & 20.8 & 23.8 & 0 \\
\hline M'Drak & 20.3 & 21.6 & 23.7 & 25.6 & 26.2 & 26.2 & 25.9 & 25.7 & 24.9 & 23.6 & 22.1 & 20.6 & 23.9 & 0 \\
\hline DakNong & 20.4 & 21.7 & 23.2 & 24.1 & 24.1 & 23.4 & 23.0 & 22.8 & 23.0 & 22.7 & 22.1 & 20.7 & 22.6 & 0 \\
\hline Da Lat & 16.2 & 17.1 & 18.1 & 19.1 & 19.6 & 19.3 & 18.8 & 18.7 & 18.7 & 18.3 & 17.5 & 16.5 & 18.0 & 4 \\
\hline Lien Khuong & 19.6 & 20.4 & 21.6 & 22.7 & 22.8 & 22.3 & 21.9 & 21.7 & 21.6 & 21.1 & 20.6 & 19.7 & 21.3 & 0 \\
\hline BaoLoc & 19.4 & 22.3 & 22.8 & 23.4 & 23.2 & 23.3 & 22.4 & 23.3 & 21.9 & 22.5 & 22.1 & 21.4 & 22.0 & 0 \\
\hline
\end{tabular}


Nguyen Khanh Van et al./Vietnam Journal of Earth Sciences 36 (2014)

Appendix 3

The totalannual rainfall and numbers of dry, arid and desert dry months ${ }^{1}$ in Tay Nguyen

\begin{tabular}{|c|c|c|c|c|c|c|}
\hline $\mathrm{N}$ & Stations & $\begin{array}{r}\text { Total annual } \\
\text { rainfall }(\mathrm{mm})\end{array}$ & $\begin{array}{c}\text { Number of rainy } \\
\text { months }\end{array}$ & $\begin{array}{c}\text { Number of dry } \\
\text { months }\end{array}$ & $\begin{array}{c}\text { Number of arid } \\
\text { months }\end{array}$ & $\begin{array}{c}\text { Number of desert } \\
\text { dry months }\end{array}$ \\
\hline I & KON TUM & & & & & \\
\hline 1 & ĐakGlei & 1694.0 & 6 & 3 & 3 & 1 \\
\hline 2 & Đak Mot & 1879.6 & 6 & 4 & 3 & 1 \\
\hline 3 & ĐacTô & 1875.5 & 6 & 4 & 3 & 1 \\
\hline 4 & $\mathrm{Pe} \mathrm{Me} \mathrm{Re}$ & 1291.8 & 6 & 4 & 3 & 2 \\
\hline 5 & Kong Plong & 1385.0 & 6 & 4 & 3 & 2 \\
\hline 6 & Sa Thay & 1802.6 & 6 & 5 & 3 & 3 \\
\hline 7 & TrungNghia & 1746.4 & 7 & 5 & 3 & 1 \\
\hline 8 & Mang Den & 1701.9 & 7 & 4 & 2 & 1 \\
\hline 9 & Kon Tum & 1806.5 & 6 & 4 & 3 & 1 \\
\hline II & GIA LAI & & & & & \\
\hline 10 & Yaly & 1793.7 & 6 & 5 & 3 & 1 \\
\hline 11 & Thon 4 & 2001.4 & 7 & 4 & 3 & 2 \\
\hline 12 & Kbang & 1388.8 & 6 & 3 & 3 & 1 \\
\hline 13 & Bien Ho & 2032.3 & 6 & 4 & 3 & 1 \\
\hline 14 & Po Me Re & 1567.7 & 6 & 4 & 4 & 3 \\
\hline 15 & Mang Yang & 1835.4 & 7 & 4 & 3 & 2 \\
\hline 16 & Pleiku & 2247.8 & 6 & 4 & 3 & 1 \\
\hline 17 & An Khe & 1552.2 & 8 & 3 & 3 & 0 \\
\hline 18 & Chu Se & 1740.4 & 6 & 4 & 4 & 2 \\
\hline 19 & Chu Prong & 2325.7 & 6 & 4 & 4 & 2 \\
\hline 20 & Auyun $\mathrm{Pa}$ & 1298.0 & 7 & 4 & 4 & 2 \\
\hline 21 & Krong Pa & 1177.1 & 6 & 5 & 3 & 2 \\
\hline III & ĐAK LAK & & & & & \\
\hline 22 & EaH'leo & 1800.7 & 6 & 4 & 4 & 2 \\
\hline 23 & KrongBuk & 1444.7 & 7 & 3 & 3 & 0 \\
\hline 24 & Ea Sup & 1549.1 & 6 & 4 & 4 & 3 \\
\hline 25 & Buon Ho & 1550.3 & 7 & 4 & 3 & 1 \\
\hline 26 & Ban Don & 1627.5 & 6 & 4 & 3 & 2 \\
\hline 27 & EaH'Dinh & 1859.2 & 7 & 4 & 4 & 1 \\
\hline 28 & Ea Knop & 1597.5 & 8 & 3 & 3 & 1 \\
\hline 29 & Buon Ma Thuot & 1814.8 & 6 & 4 & 3 & 2 \\
\hline 30 & M'Drak & 2258.2 & 8 & 2 & 0 & 0 \\
\hline 32 & EaKmat & 1943.2 & 7 & 4 & 3 & 1 \\
\hline 31 & KrongKmar & 1873.1 & 8 & 4 & 3 & 2 \\
\hline 33 & GiangSơn & 1895.2 & 8 & 3 & 2 & 0 \\
\hline 34 & Lak & 2029.1 & 7 & 4 & 3 & 2 \\
\hline IV & ĐAK NONG & & & & & \\
\hline 35 & Cau 14 & 1708.7 & 6 & 4 & 3 & 2 \\
\hline 36 & Duc Lap & 1788.1 & 7 & 4 & 3 & 1 \\
\hline 37 & Đak Mil & 1796.8 & 7 & 4 & 3 & 0 \\
\hline 38 & ĐucXuyen & 1914.6 & 7 & 4 & 3 & 1 \\
\hline 39 & ĐacNong & 2563.6 & 8 & 3 & 2 & 0 \\
\hline V & LAM ĐONG & & & & & \\
\hline 40 & ĐamRong & 2010.8 & 8 & 4 & 3 & 1 \\
\hline 41 & ĐaNhim & 1584.9 & 8 & 2 & 2 & 0 \\
\hline 42 & XaLat & 2013.7 & 8 & 3 & 1 & 0 \\
\hline 43 & SuoiVang & 1865.3 & 8 & 3 & 2 & 0 \\
\hline 44 & ĐaLat & 1865.0 & 7 & 3 & 2 & 0 \\
\hline 45 & Nam Ban & 1689.4 & 7 & 3 & 3 & 0 \\
\hline 46 & Lac Nghiep & 1344.9 & 7 & 4 & 3 & 2 \\
\hline 47 & ThanhBinh & 1581.9 & 7 & 3 & 3 & 1 \\
\hline 48 & Đon Duong & 1397.8 & 6 & 4 & 2 & 2 \\
\hline 49 & Lien Khuong & 1567.8 & 7 & 3 & 3 & 1 \\
\hline 50 & ĐaiNinh & 1331.2 & 6 & 4 & 3 & 0 \\
\hline 51 & Cat Que & 2461.8 & 8 & 3 & 3 & 0 \\
\hline 52 & PhuGia & 1322.2 & 6 & 4 & 3 & 2 \\
\hline 53 & Di Linh & 1644.4 & 7 & 4 & 2 & 0 \\
\hline 54 & DạTeh & 3126.8 & 8 & 3 & 2 & 0 \\
\hline 55 & ĐaiNga & 2206.8 & 8 & 2 & 0 & 0 \\
\hline 56 & BaoLoc & 2815.3 & 9 & 0 & 0 & 0 \\
\hline
\end{tabular}

${ }^{1}$ Dry month - a month, in which totalmonthly rainfall $r(\mathrm{~mm})$ equal or twice lower than monthly average temperature $t\left({ }^{\circ} \mathrm{C}\right): r \leq 2 t ;$ Arid month: $r \leq t$; Desert dry month: $r \approx 0$. According to Thai Van Trung, $1978(6)$ in tropic region such as Vietnam, the dry month, arid month and desert dry month have total monthly rainfall approximately $50 \mathrm{~mm}, 25 \mathrm{~mm}$ and $5 \mathrm{~mm}$, respectively. 